\title{
Analiza zależności na rynkach finansowych Europy Środkowej
}

Paweł Sekuła*

\section{Wstęp}

Zmiany ustrojowe na początku lat 90. XX w. w Europie Centralnej pociągnęły za sobą rewolucyjne zmiany gospodarcze. Państwa w gwałtownym procesie zmieniły model gospodarki z centralnie planowanego na model gospodarki rynkowej. W ciągu kilkunastu lat powstał rozwinięty rynek finansowy, a państwa Europy Centralnej stały się uczestnikami międzynarodowej wymiany kapitałowej.

Umiędzynarodowianie operacji na rynkach finansowych trwa już od wielu lat i jest zjawiskiem zmiennym, które okresowo przyspiesza lub zwalnia (Lothian 2002). Dlatego za cel pracy obrano przeanalizowanie krótko- i długookresowych zależności między rynkami akcji, walut i obligacji skarbowych w Czechach, Polsce i na Węgrzech. Starano się odpowiedzieć na pytania o to, czy dominuje model portfelowej, regionalnej alokacji kapitału? Czy inwestorzy zagraniczni, podejmując decyzje o inwestycjach portfelowych lub o wycofaniu kapitałów, traktują wymienione państwa jako jeden wspólny cel inwestycyjny, czy jednak różnicują podejście, starając się uwzględniać atrakcyjność i ryzyko poszczególnych rynków? Czy ewentualnie występują odpowiednio silne wspólne determinanty kształtowania cen w państwach Europy Centralnej, sprawiające, że przebieg notowań instrumentów na różnych rynkach jest podobny?

Biorąc pod uwagę dość niejednoznaczne wyniki dotychczasowych badań, zdecydowano się na postawienie dwóch hipotez badawczych - o istotnym skorelowaniu badanych zmiennych oraz o występowaniu kointegracji świadczącej o długookresowej równowadze między zmiennymi.

* Paweł Sekuła - doktor, Uniwersytet Łódzki, Wydział Zarządzania, Katedra Zarządzania Finansami Przedsiębiorstwa, pawel.sekula@uni.lodz.pl 


\section{Przegląd literatury}

Początkowo badania nad zależnościami na rynkach finansowych dotyczyły głównie giełd akcyjnych. Zależności korelacyjne między stopami zwrotu rynków akcji badał Agmon (1972). Hilliard, wykorzystując dzienne ceny zamknięcia notowań, wskazywał na powiązania między głównymi indeksami na rynkach światowych (Hilliard 1979). Krach giełdowy w październiku 1987 r. skłonił do badania przyczynowości. Analizy potwierdziły występowanie zależności między rynkami w okresie załamania koniunktury (Malliaris, Urrita 1992). W latach 80. zaczęto analizować związki między cenami akcji a kursami walut. Zaproponowano modele kursów walutowych, które koncentrowały się na rachunku bieżącym i bilansie handlowym (Dornbusch, Fischer 1980) czy relacjach rynkowych (Branson 1983; Frankel 1983). W ich przypadku rachunek kapitałowy miał istotny wpływ na dynamikę kursu walutowego. Badania koncentrowały się wówczas na analizie relacji między stopami zwrotu akcji a kursami walut. Aggarwal (1981) stwierdził, że ceny akcji w Stanach Zjednoczonych i kurs dolara amerykańskiego są dodatnio skorelowane. Do odmiennych wniosków doszli Soenen i Hennigar (1988), którzy wskazywali na korelację ujemną. Rozbieżności między badaniami próbowali tłumaczyć Ma i Kao (1990) - ich zdaniem aprecjacja waluty miała negatywny wpływ na ceny akcji w przypadku gospodarek zdominowanych przez eksport, a pozytywny w przypadku gospodarek zdominowanych przez import. Analizy zależności między rynkami wskazywały również na występowanie związków między stopami zwrotu akcji a obligacjami oraz na zmienność ich korelacji w czasie (Ilmanen 2003; Anderson $i$ in. 2008).

Z badań zależności między rynkami akcji w Europie Środkowej wynikało, że były to związki kointegracyjne, jednak państwa Europy Środkowej miały silniejsze relacje rynkowe z krajami rozwiniętymi niż z pozostałymi krajami regionu (Syriopoulos 2004). Syllignakis i Kouretas wskazywali na szczególnie silny wpływ rynków rozwiniętych na giełdy w Europie Środowej w okresach kryzysu (Syllignakis, Kouretas 2011). Demian, który badał wpływ przystąpienia do UE na kointegrację rynków rozwiniętych z rynkami z Europy Środowej, doszedł do wniosku, że akcesja do UE niewiele zmieniła w relacjach między rynkami - większe znaczenie miały czynniki ekonomiczne (Demian 2011).

W badaniach analizowano również relacje między GPW w Warszawie a międzynarodowymi rynkami kapitałowymi (Zielonka, Foltyński 1999; Fiszeder 2000). Po zweryfikowaniu zależności między indeksami BUX, PX, WIG i STOXX50 przy użyciu wielowymiarowych modeli GARCH stwierdzono, że korelacje między rynkami są silne i wzrosły po wejściu do UE (Gjika, Horvath 2013). Analiza korelacji indeksów akcji w latach 1999-2011 pozwoliła dostrzec znaczące różnice, jeśli chodzi o siłę związków. W okresach krótszych związki 
między indeksami były zwykle silniejsze, a wydłużenie okresu powodowało wyraźne osłabienie zależności (Hołubowicz 2014).

W badaniach zwracano uwagę również na wpływ dynamiki kursu walutowego na rynek akcji (Doman, Doman 2011). Buszkowska zauważyła słabe ujemne korelacje między przyrostami kursów walutowych a przyrostami WIG20, ale nie stwierdziła kointegracji (Buszkowska 2014). Kliber i Kliber (2010) analizowali zależności między kursami walut Europy Środkowej w kontekście kryzysu z 2008 r. Witkowska, która badała kointegrację kursów walutowych Czech, Polski i Węgier, po przeanalizowaniu danych z lat 2008-2009 stwierdziła występowanie relacji kointegrującej między EUR/HUF i EUR/CZK oraz między EUR/PLN i EUR/CZK (Witkowska 2011). Nie odnotowano natomiast zależności kointegracyjnych między WIG a indeksem polskich obligacji skarbowych w latach 2011-2016 (Dyduch 2016). W badaniach pojawiły się również wnioski dotyczące zmian siły zależności między instrumentami w poszczególnych państwach, np. Czapkiewicz i Jamer (2015) podkreślali osłabienie współzależności po $2012 \mathrm{r}$.

\section{Opis próby i metoda badawcza}

Badanie zależności krótko- i długookresowych na rynkach finansowych w Europie Środkowej przeprowadzono na podstawie danych z Czech, Polski i Węgier. Przeanalizowano następujące rynki: akcji, walutowy i rynek długoterminowej stopy procentowej. Zmiany koniunktury na rynku akcji opisywały trzy indeksy akcyjne: PX giełdy praskiej, BUX giełdy w Budapeszcie i WIG, najszerszy indeks akcji giełdy w Warszawie. Rynek walutowy badano, porównując bezpośredni kurs walut regionalnych z kursem euro (EUR) i dolara amerykańskiego (USD). Otrzymano po dwa kursy walutowe wyznaczone dla czeskiej korony (CZK), węgierskiego forinta (HUF) i polskiego złotego (PLN). Za odpowiednik rynkowej długoterminowej stopy procentowej przyjęto rentowność 10-letnich obligacji skarbowych, które na światowym rynku finansowym są instrumentami benchmarkowymi. W badaniach wykorzystano szeregi czasowe przeciętnych stóp zwrotu w terminie wykupu 10-letnich obligacji: czeskich (10CZY), węgierskich (10HUY) i polskich (10PLY).

Po przeanalizowaniu szeregów czasowych zmiennych obejmujących okres od początku stycznia 2006 r. do końca grudnia 2019 r., pobranych z serwisu stooq.pl, otrzymano 731 obserwacji. Zdecydowano się na dane o częstotliwości tygodniowej ze względu na ich mniejszą zmienność i większą odporność na zaburzenia losowe. Aby ułatwić obserwację stabilności zależności w zmieniającym się otoczeniu gospodarczym okres badawczy podzielono na dwa podokresy. Pierwszy obejmował zakres danych od stycznia 2006 r. do grudnia 2012 r., a drugi od 
stycznia 2013 r. do grudnia 2019 r. Pierwszy podokres objął kryzys z roku 2008, poprzedzający go szczyt koniunkturalny oraz kryzys zadłużeniowy państw strefy euro w latach 2010-2011. Drugi podokres to czas stopniowej normalizacji sytuacji ekonomicznej po załamaniu w roku 2008.

W międzynarodowych transferach kapitałów Czechy, Polska i Węgry mogą być lokowane w tej samej kategorii rynków, jednak przegląd indeksów koniunktury pokazuje, że są między nimi pewne różnice. Zmiany analizowanych danych w badanym okresie przedstawiono na Wykresach 1-5.

Wykres 1 przedstawia koniunkturę na rynkach akcji. Dla ułatwienia porównania prezentowane dane zostały przekształcone, tzn. dla każdego z rynków akcji wyznaczono syntetyczne indeksy - na początku badanego okresu (1.01.2006) poziom indeksów jest równy jedności, a zmiany indeksów w kolejnych tygodniach odzwierciedlają zmiany indeksów giełdowych. Wzrosty na giełdach powodowały zwyżki indeksów syntetycznych, a spadki ich zniżki. Dynamika koniunktury na poszczególnych giełdach była oczywiście różna i podążała za głównymi rynkami akcji, jednak do początku 2015 r. zachowanie indeksów akcji w badanych państwach było dość zbieżne. Najwyższą skumulowaną stopę zwrotu odnotował WIG, a najniższą PX. Mogło to wynikać ze skali rynku w Polsce oraz rozwiązań instytucjonalnych - obligatoryjnych funduszy emerytalnych inwestujących tylko w krajowe aktywa, co przekładało się na wyceny polskich spółek z premią. Istotne zmiany nastąpiły w 2015 r., kiedy to rynek węgierski stał się najsilniejszy, zyskując nawet wtedy, kiedy giełdy w Polsce i Czechach tracily.

Do zobrazowania koniunktury na rynku walutowym w badanym okresie także użyto syntetycznych indeksów. Na początku okresu badawczego również przyjęto wartość indeksu równą jedności, ale wyznaczając zmiany, postępowano inaczej niż w przypadku rynku akcji. Jeśli kurs walutowy rósł, to procentowy wzrost kursu obniżał poziom syntetycznego indeksu, a jeśli kurs walutowy spadał, to procentowa zmiana kursu podnosiła wartość syntetycznego indeksu. Założono tym samym, że osłabienie waluty krajowej obniża indeks, a umocnienie waluty podnosi jego wartość. Wykresy 2 i 3, obrazujące syntetyczne indeksy walutowe, pokazują, że w całym badanym okresie kursy walutowe były dość zbieżne, przy czym korona czeska była najmocniejszą walutą, a węgierski forint - najsłabszą. Wynikało to najprawdopodobniej z dość istotnych różnic w parametrach makroekonomicznych państw. 
Wykres 1. Syntetyczne indeksy akcji w okresie styczeń 2006 - grudzień 2019

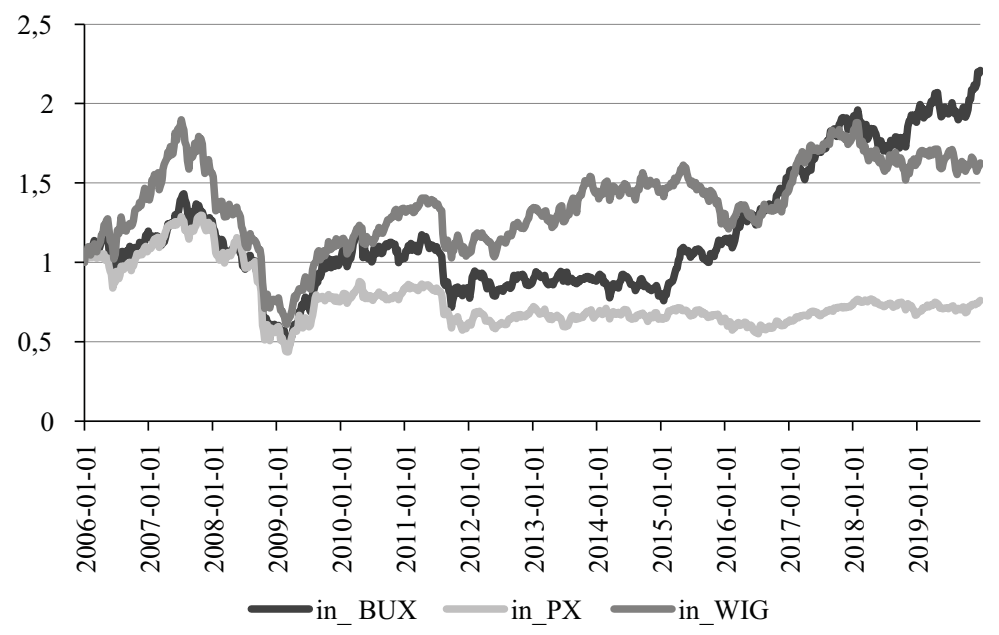

Źródło: opracowanie własne.

Wykres 2. Syntetyczne indeksy walutowe wyznaczone względem EUR dla okresu styczeń 2006 - grudzień 2019

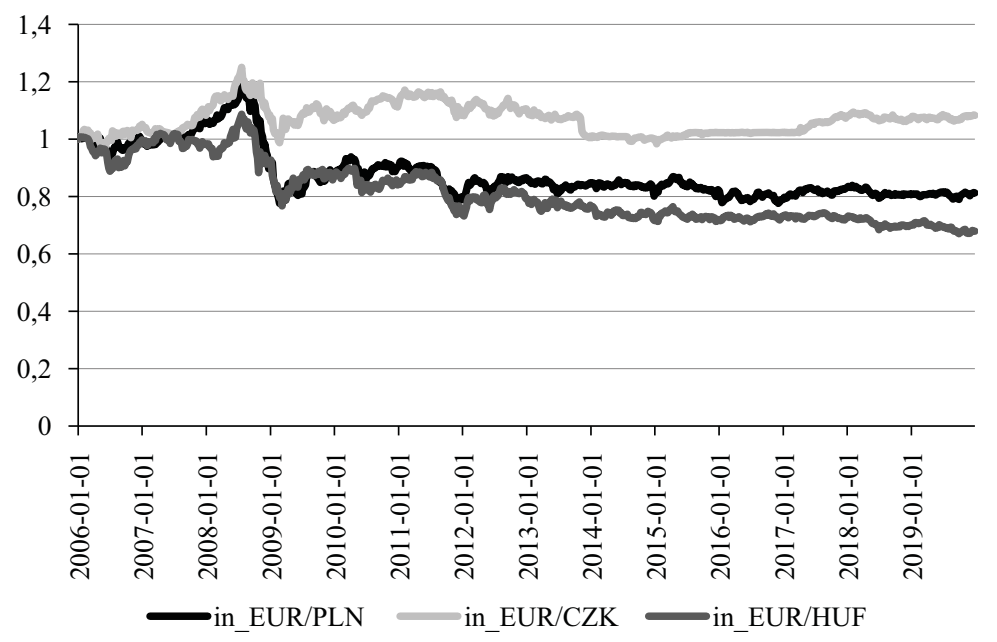

Źródło: opracowanie własne. 
Wykres 3. Syntetyczne indeksy walutowe wyznaczone względem USD dla okresu styczeń 2006 - grudzień 2019

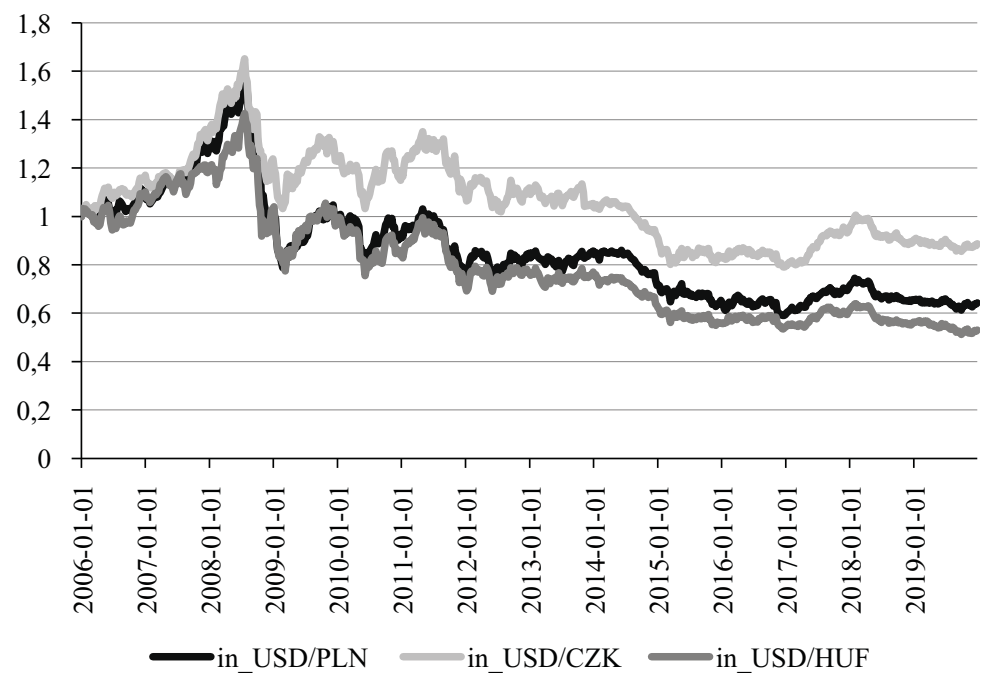

Źródło: opracowanie własne.

Do przeanalizowania rynku długoterminowej stopy procentowej wykorzystano rentowność 10-letnich obligacji skarbowych. Na Wykresach 4 i 5 zaprezentowano rentowność obligacji oraz premię obligacji Czech, Polski i Węgier względem niemieckich 10-letnich obligacji skarbowych. Zmiany rentowności w poszczególnych państwach do końca 2015 r. były dość podobne, choć oczywiście występowały istotne różnice, jeśli chodzi o poziom wymaganych dochodowości. Najwyższa dochodowość była w przypadku Węgier - w 2009 r. wynosiła ponad 12 punktów procentowych (p.p.), podczas gdy w przypadku Czech nie przekroczyła 6 p.p., co odzwierciedlało różnice makroekonomiczne między państwami. Wraz z nasilaniem się zjawisk kryzysowych rentowność rosła, ale już od 2012 r. obserwowaliśmy wieloletni trend spadkowy. Był on efektem prowadzenia nowej polityki pieniężnej na świecie, skutkującej wielkimi operacjami skupu obligacji i spadkiem rynkowych stóp procentowych. Od 2016 r. można obserwować istotne zmiany w relacjach wysokości rentowności obligacji. Nastąpił wyraźny względny spadek rentowności obligacji węgierskich oraz wzrost rentowności obligacji czeskich. Pod koniec 2019 r. najwyższą rentowność miały obligacje polskie $(2,072 \%)$, a najniższą czeskie $(1,552 \%)$. W tym samym czasie rentowność obligacji węgierskich wyniosła $1,965 \%$. Zmiany te dobrze ilustruje relacja między premią obligacji państw Europy Środkowej a rentownością obligacji niemieckich. W ostatnich dwóch latach premia dla obligacji czeskich wzrosła o prawie 2 p.p., podczas gdy dla instrumentów węgierskich spadła do 2,22\% (z 8\% w 2012 r. ). Zmiany te były spowodowane polityką pieniężną, która znacząco ograniczyła różnice w koszcie kapitału między poszczególnymi państwami. 
Wykres 4. Rentowności 10-letnich obligacji skarbowych w okresie styczeń 2006 - grudzień 2019

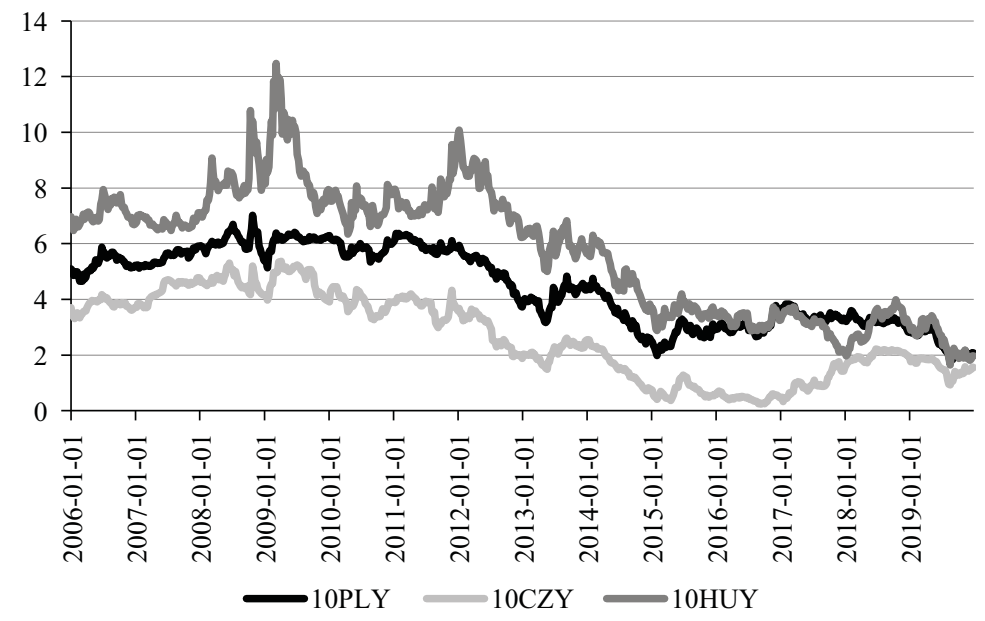

Źródło: opracowanie własne.

Wykres 5. Różnica między rentownością 10-letnich obligacji państw Europy Środkowej a rentownością 10-letnich obligacji niemieckich w okresie styczeń 2006 - grudzień 2019

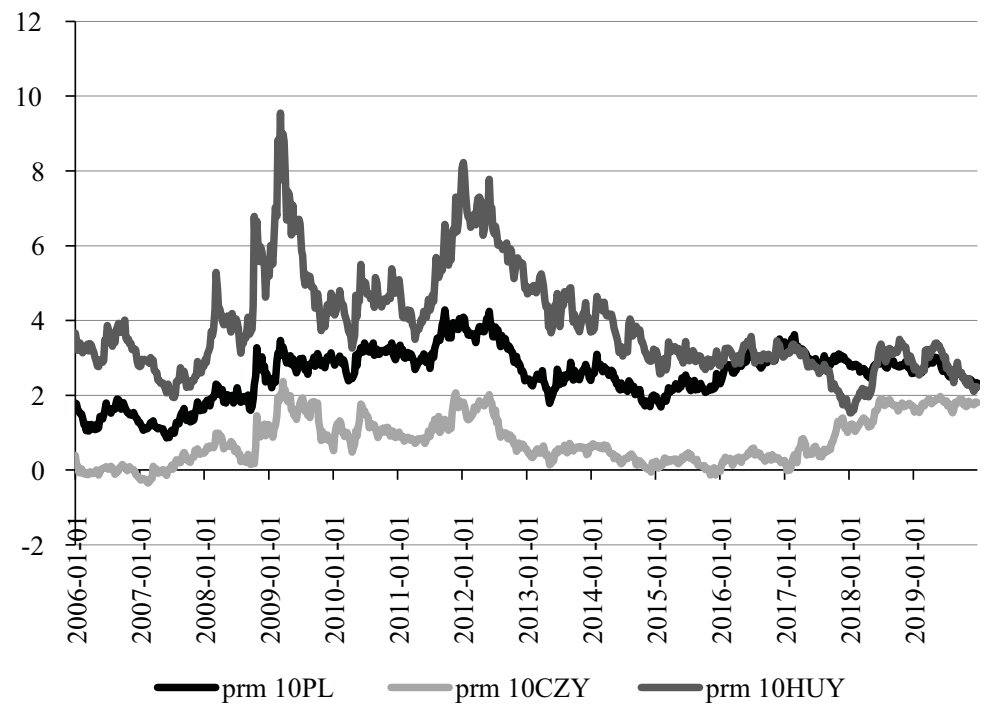

Źródło: opracowanie własne.

Charakterystyki opisowe szeregów czasowych zmiennych zamieszczono w Tabeli 1. Analizowano tygodniowe dane o notowaniach trzech indeksów akcyjnych, sześciu kursów walutowych i trzech szeregów z informacjami o poziomach rentowności obligacji. Dane o notowaniach instrumentów na rynkach finansowych charakteryzują się dużą zmiennością. W badaniach najwyższe 
Tabela 1. Statystyki opisowe zmiennych dla obserwacji tygodniowych w okresie styczeń 2006 - grudzień 2019

\begin{tabular}{|l|c|c|c|c|c|c|c|c|}
\hline \multicolumn{1}{|c|}{ Zmienna } & Średnia & Mediana & Min & Max & $\begin{array}{c}\text { Odchylenie } \\
\text { stand. }\end{array}$ & $\begin{array}{c}\text { Wspól. } \\
\text { zmienności }\end{array}$ & Skośność & Kurtoza \\
\hline BUX & 24636,10 & 22327,0 & 9852,83 & 45984,50 & 8080,20 & 0,3280 & 0,8395 & $-0,2928$ \\
\hline PX & 1129,25 & 1038,89 & 640,90 & 1910,10 & 263,62 & 0,2335 & 1,2760 & 0,8218 \\
\hline WIG & 48709,20 & 48446,40 & 21690,80 & 67568,50 & 9226,05 & 0,1894 & $-0,3713$ & $-0,1134$ \\
\hline EUR/CZK & 26,2779 & 25,9098 & 22,9640 & 29,8310 & 1,2602 & 0,0479 & 0,2477 & $-0,6308$ \\
\hline EUR/HUF & 29,610 & 296,280 & 228,190 & 335,311 & 24,9359 & 0,0858 & $-0,3802$ & $-0,9877$ \\
\hline EUR/PLN & 4,1086 & 4,1749 & 3,2038 & 4,7386 & 0,2568 & 0,0625 & $-1,1073$ & 1,3514 \\
\hline USD/CZK & 20,8922 & 20,6740 & 14,4970 & 26,0100 & 2,5408 & 0,1216 & $-0,0334$ & $-0,8335$ \\
\hline USD/HUF & 232,360 & 223,850 & 144,010 & 306,454 & 39,9841 & 0,1721 & 0,0623 & $-1,1399$ \\
\hline USD/PLN & 3,2762 & 3,2011 & 2,0265 & 4,2308 & 0,4688 & 0,1431 & $-0,2112$ & $-0,4699$ \\
\hline 10CZY & 2,67505 & 2,35600 & 0,24400 & 5,36500 & 1,4964 & 0,5594 & 0,0044 & $-1,3643$ \\
\hline 10HUY & 5,75409 & 6,51000 & 1,65000 & 12,47000 & 2,2967 & 0,3991 & 0,0464 & $-0,9969$ \\
\hline 10PLY & 4,44376 & 4,47900 & 1,73400 & 7,01900 & 1,3610 & 0,3083 & $-0,1113$ & $-1,4602$ \\
\hline
\end{tabular}

Źródło: opracowanie własne. 
współczynniki zmienności odnotowano w przypadku szeregów rentowności obligacji i wartości indeksów akcji, a najbardziej stabilne okazały się kursy walutowe, przede wszystkim te wyznaczane względem EUR. Szeregi danych finansowych charakteryzowały się asymetrią rozkładu. W przypadku polskich instrumentów finansowych odnotowano lewostronnie asymetryczne rozkłady danych, charakteryzujące się tzw. „ciężkim lewym ogonem”. Kursy walutowe względem EUR również były lewostronnie asymetryczne, natomiast rozkłady pozostałych instrumentów finansowych z Czech i Węgier miały rozkłady prawostronnie asymetryczne. Ponadto rozkłady badanych notowań najczęściej były platokurtyczne, co oznacza, że wartości ich cech w porównaniu z normalnym rozkładem były mniej skoncentrowane. W przypadku PX i EUR/PLN wystąpiły rozkłady leptokurtyczne.

W kolejnym etapie badania przeprowadzono analizę stacjonarności szeregów czasowych zmiennych, wykorzystując dwa testy: rozszerzony test pierwiastka jednostkowego Dickey'a-Fullera (ADF) oraz test Kwiatkowskiego, Phillipsa, Schmidta, Shina (KPSS).

Test ADF weryfikuje hipotezę zerową, zgodnie z którą szereg jest niestacjonarny z powodu występowania pierwiastka jednostkowego. Jeśli wyznaczona wartość statystki jest mniejsza od wartości krytycznej, to hipoteza zerowa odrzucana jest na rzecz hipotezy alternatywnej, zgodnie z którą szereg jest stacjonarny (Dickey, Fuller 1979).

W przypadku badanych poziomów zmiennych wartości statystyk testu ADF były wyższe od wartości krytycznych, zatem nie było podstaw do odrzucenia hipotezy zerowej o występowaniu pierwiastka jednostkowego. W przypadku analizy pierwszych różnic zmiennych statystyki testu ADF były niższe od wartości krytycznych, co dawało podstawy do odrzucenia hipotezy zerowej. Przeprowadzone testy wykazały, że szeregi tygodniowych notowań charakteryzowały się brakiem stacjonarności, a pierwsze różnice zmiennych były stacjonarne.

Test stacjonarności KPSS w hipotezie zerowej zakłada stacjonarność badanego szeregu zmiennych, a w hipotezie alternatywnej - występowanie pierwiastka jednostkowego (Kwiatkowski i in. 1992). Dla badanych zmiennych wyniki testów dały podstawy do odrzucenia hipotezy zerowej o stacjonarności na rzecz hipotezy alternatywnej o jej braku. W przypadku pierwszych różnic zmiennych nie było podstaw do odrzucenia hipotezy zerowej. Wyniki testu KPSS okazały się więc zgodne $\mathrm{z}$ wynikami testu ADF.

Przeprowadzone testy, w których poziomy zmiennych były niestacjonarne, a pierwsze różnice zmiennych stacjonarne, pozwoliły stwierdzić, że szeregi zmiennych są zintegrowane w stopniu pierwszym. 
Tabela 2. Test stacjonarności ADF, test z wyrazem wolnym

\begin{tabular}{|l|c|c|c|c|}
\hline \multirow{2}{*}{ Zmienna } & \multicolumn{2}{|c|}{ Poziomy zmiennych } & \multicolumn{2}{c|}{ Pierwsze różnice } \\
\cline { 2 - 5 } BUX & Statystyka testu & $\mathbf{p}$ & Statystyka testu & $\mathbf{p}$ \\
\hline PX & 0,1798 & 0,9714 & $-5,6785$ & 0,0000 \\
\hline WIG & $-2,4519$ & 0,1276 & $-5,3522$ & 0,0000 \\
\hline EUR/CZK & $-2,3576$ & 0,1541 & $-4,7639$ & 0,0000 \\
\hline EUR/HUF & $-3,1593$ & 0,0225 & $-5,6859$ & 0,0000 \\
\hline EUR/PLN & $-1,4099$ & 0,5791 & $-6,4230$ & 0,0000 \\
\hline USD/CZK & $-3,0355$ & 0,0317 & $-6,0343$ & 0,0000 \\
\hline USD/HUF & $-2,0553$ & 0,2632 & $-26,7934$ & 0,0000 \\
\hline USD/PLN & $-1,0633$ & 0,7324 & $-7,1950$ & 0,0000 \\
\hline 10CZY & $-1,8676$ & 0,3480 & $-6,3282$ & 0,0000 \\
\hline 10HUY & $-1,0487$ & 0,7378 & $-5,7833$ & 0,0000 \\
\hline 10PLY & $-0,5286$ & 0,8833 & $-10,6885$ & 0,0000 \\
\hline
\end{tabular}

Źródło: opracowanie własne.

Tabela 3. Test stacjonarności KPSS

\begin{tabular}{|l|c|c|}
\hline \multirow{2}{*}{ Zmienna } & Poziomy zmiennych & Pierwsze różnice \\
\cline { 2 - 3 } & $\begin{array}{c}\text { Statystyka testu } \\
\text { Wartość krytyczna }(\boldsymbol{\alpha}=\mathbf{0 , 0 5}) \mathbf{0 , 4 6 2}\end{array}$ & $\begin{array}{c}\text { Statystyka testu } \\
\text { Wartość krytyczna }(\boldsymbol{\alpha}=\mathbf{0 , 0 5}) \mathbf{0 , 4 6 2}\end{array}$ \\
\hline BUX & 5,3600 & 0,3555 \\
\hline PX & 4,6127 & 0,0849 \\
\hline WIG & 3,9421 & 0,0581 \\
\hline EUR/CZK & 1,0708 & 0,1061 \\
\hline EUR/HUF & 9,0848 & 0,0158 \\
\hline EUR/PLN & 4,8302 & 0,0270 \\
\hline USD/CZK & 4,3614 & 0,1880 \\
\hline USD/HUF & 8,6542 & 0,0738 \\
\hline USD/PLN & 7,1216 & 0,0688 \\
\hline $\mathbf{1 0 C Z Y ~}$ & 8,4971 & 0,1061 \\
\hline $\mathbf{1 0 H U Y}$ & 8,3983 & 0,0787 \\
\hline $\mathbf{1 0 P L Y}$ & 8,5720 & 0,1336 \\
\hline
\end{tabular}

Źródło: opracowanie własne.

Aby przeanalizować zależności krótkookresowe między zmiennymi, wykorzystano współczynnik korelacji Pearsona. Wzór na współczynnik korelacji liniowej Pearsona jest wyznaczony przez standaryzację kowariancji:

$$
r_{x y}=\frac{\sum_{i=1}^{n}\left(x_{i}-\bar{x}\right)\left(y_{i}-\bar{y}\right)}{\sqrt{\sum_{i=1}^{n}\left(x_{i}-\bar{x}\right)^{2} \sum_{i=1}^{n}\left(y_{i}-\bar{y}\right)^{2}}}=\frac{\operatorname{cov}(X, Y)}{s_{x} s_{y}}
$$

gdzie: $\bar{x}, \bar{y}$ to średnie zmiennych, a $s_{x}, s_{y}$ to odchylenia standardowe zmiennych. 
Współczynnik przyjmuje wartości z przedziału $[-1,1]$ i jest miernikiem siły związku prostoliniowego między dwiema zmiennymi. Znak współczynnika informuje o kierunku korelacji, a jego bezwzględna wartość o sile związku. Biorąc pod uwagę zastrzeżenia wobec współczynnika korelacji (Embrechts i in. 1999), zdecydowano się na wyznaczenie korelacji dla pierwszych różnic stacjonarnych zmiennych. Niestacjonarność poziomów zmiennych mogłaby powodować ryzyko wystąpienia korelacji przypadkowych.

Do zbadania długoterminowych zależności między zmiennymi wykorzystano kointegrację. Metoda ta, sformułowana przez Grangera (1981) i rozwinięta przez Engle'a i Grangera (1987), polega na połączeniu dynamiki krótkookresowej z równowagą długookresową. Zmienne skointegrowane wykazują takie same tendencje i zmierzają do równowagi długookresowej. Jeżeli szereg $y_{t}$ jest zintegrowany w stopniu $1, y_{t} \sim I(1)$, a szereg $x_{t}$ również jest zintegrowany $\mathrm{w}$ stopniu 1, $x_{t} \sim I(1)$, to można powiedzieć, że $y_{t}$ i $x_{t}$ są skointegrowane, jeśli istnieje takie $\beta$, że

$$
y_{t}-\beta x_{t}
$$

jest $I(0)$. Oznacza to, że składnik losowy jest stacjonarny. Wówczas równanie regresji

$$
y_{t}-\beta x_{t}=u_{t}
$$

odpowiada sytuacji, w której $y_{t}$ i $x_{t}$ nie oddalają się od siebie znacząco wraz z upływem czasu, czyli występuje między nimi relacja długookresowej równowagi. Jeśli $y_{t}$ i $x_{t}$ nie są skointegrowane, czyli $y_{t}=\beta x_{t}+u_{t}$ jest $I(1)$, to nie występuje między nimi relacja długookresowej równowagi, a związek jest pozorny (Maddala 2006, s. 622-623).

Kointegrację w procedurze Engle'a-Grangera można badać w czterech krokach. W pierwszym i drugim kroku przeprowadzany jest test jednostkowy dla zmiennej pierwszej i drugiej. Weryfikowana jest hipotez zerowa - występuje pierwiastek jednostkowy $a=1$, proces jest $I(1)$. W kroku trzecim estymowane jest równanie kointegrujące. Krok czwarty to test na pierwiastek jednostkowy dla procesu resztowego z równania kointegrującego. Weryfikowana jest hipotez zerowa - występuje pierwiastek jednostkowy $a=1$, proces jest $I(1)$. Przyjmuje się wówczas, że kointegracja występuje, jeżeli każdy wykorzystany proces jest $I(1)$, tzn. hipoteza zerowa o pierwiastku jednostkowym nie została odrzucona i proces resztowy z równania kointegrującego nie jest zintegrowany, a hipoteza zerowa o pierwiastku jednostkowym została odrzucona. 


\section{Wyniki analizy}

Zależności krótkoterminowe między poszczególnymi segmentami rynku finansowego w wybranych państwach Europy Środkowej zbadano za pomocą współczynników korelacji liniowej Pearsona. Mając na uwadze pewne ograniczenia badawcze miar korelacji, zdecydowano się na analizę pierwszych różnic zmiennych. Nie wykorzystano poziomów zmiennych niestacjonarnych, aby ograniczyć ryzyko wystąpienia korelacji przypadkowych. W celu zbadania stabilności zależności krótkoterminowych między zmiennymi próbę podzielono na dwa podokresy: od stycznia 2006 r. do grudnia 2012 r. oraz od stycznia 2013 r. do grudnia 2019 r. Wyniki analizy uwzględniającej oba podokresy zamieszczono w Tabelach 4 i 5.

Nawet pobieżne porównanie macierzy korelacji w dwóch podokresach pozwala zauważyć dość dużą różnicę w liczbie korelacji przeciętnych i wysokich między badanymi zmiennymi. W pierwszym podokresie odnotowano 19 korelacji wysokich i 28 przeciętnych, a w drugim podokresie tylko 8 wysokich i 12 przeciętnych. Wskazywałoby to na postępujące różnicowanie się segmentów rynku finansowego poszczególnych państw. Może to oznaczać, że na lokowanie kapitału międzynarodowego w Europie Środkowej coraz większy wpływ mają stan i atrakcyjność każdego z rynków poszczególnych państw, a cały region przestaje być postrzegany jako jeden wspólny cel alokacji.

Tabela 4. Współczynniki korelacji liniowej pierwszych różnic dla obserwacji tygodniowych w okresie styczeń 2006 - grudzień 2019

\begin{tabular}{|c|c|c|c|c|l|}
\hline d_WIG & d_PX & d_BUX & d_EUR/PLN & d_EUR/CZK & \\
\hline 1,0000 & 0,7152 & 0,6696 & $-0,4306$ & $-0,0838$ & d_WIG \\
\hline & 1,0000 & 0,6989 & $-0,4824$ & $-0,0510$ & d_PX \\
\hline & & 1,0000 & $-0,5124$ & $-0,1111$ & d_BUX \\
\hline & & & 1,0000 & 0,4797 & d_EUR/PLN \\
\hline & & & & 1,0000 & d_EUR/CZK \\
\hline d_EUR/HUF & d_USD/PLN & d_USD/CZK & d_USD/HUF & d_10PLY & \\
\hline$-0,3813$ & $-0,4782$ & $-0,3202$ & $-0,4246$ & $-0,2943$ & d_WIG \\
\hline$-0,4097$ & $-0,4970$ & $-0,2829$ & $-0,4312$ & $-0,3954$ & d_PX \\
\hline$-0,4625$ & $-0,5566$ & $-0,3751$ & $-0,5030$ & $-0,3785$ & d_BUX \\
\hline 0,6658 & 0,8165 & 0,5028 & 0,5858 & 0,4351 & d_EUR/PLN \\
\hline 0,3691 & 0,3815 & 0,5507 & 0,3037 & 0,0823 & d_EUR/CZK \\
\hline 1,0000 & 0,6616 & 0,5080 & 0,8534 & 0,4313 & d_EUR/HUF \\
\hline & 1,0000 & 0,8360 & 0,8629 & 0,4016 & d_USD/PLN \\
\hline & & 1,0000 & 0,8018 & 0,2176 & d_USD/CZK \\
\hline & & & 1,0000 & 0,3818 & d_USD/HUF \\
\hline & & & & 1,0000 & d_10PLY \\
\hline
\end{tabular}




\begin{tabular}{|l|l|l|c|c|l|}
\hline & & & d_10CZY & d_10HUY & \\
\hline & & & $-0,0926$ & $-0,3217$ & d_WIG \\
\hline & & & $-0,0968$ & $-0,3940$ & d_PX \\
\hline & & & $-0,0488$ & $-0,4169$ & d_BUX \\
\hline & & & 0,1595 & 0,4718 & d_EUR/PLN \\
\hline & & & 0,0100 & 0,1761 & d_EUR/CZK \\
\hline & & & 0,1669 & 0,6172 & d_EUR/HUF \\
\hline & & & 0,1361 & 0,4481 & d_USD/PLN \\
\hline & & & 0,0643 & 0,2844 & d_USD/CZK \\
\hline & & & 0,1304 & 0,5307 & d_USD/HUF \\
\hline & & & 0,3930 & 0,4738 & d_10PLY \\
\hline & & & 1,0000 & 0,2289 & d_10CZY \\
\hline & & & & 1,0000 & d_10HUY \\
\hline
\end{tabular}

Źródło: opracowanie własne.

Rynki akcji w poszczególnych państwach były dość wysoce skorelowane. W pierwszym podokresie wystąpiły wysokie dodatnie współczynniki korelacji, które w drugim podokresie obniżyły się do wartości przeciętnych. Można zauważyć, że na rynki w Europie Środkowej oddziaływały wspólne czynniki, ale widoczne jest także osłabianie się relacji między tymi rynkami. W pierwszym podokresie odnotowano również przeciętne ujemne korelacje między rynkiem akcji a rynkiem walut. Jest to prawdopodobnie efektem pewnych zależności wynikających z międzynarodowych transferów kapitałów. Napływ kapitału zagranicznego do państw Europy Środkowej mógł umacniać waluty krajowe, obniżając kursy walutowe, a nowe środki mogły trafiać na giełdy w regionie, wpływając na zwyżki indeksów akcji.

Tabela 5. Współczynniki korelacji liniowej pierwszych różnic dla obserwacji tygodniowych w okresie styczeń 2006 - grudzień 2019

\begin{tabular}{|c|c|c|c|c|l|}
\hline d_WIG & d_PX & d_BUX & d_EUR/PLN & d_EUR/CZK & \\
\hline 1,0000 & 0,5259 & 0,4617 & $-0,3998$ & $-0,0795$ & d_WIG \\
\hline & 1,0000 & 0,4370 & $-0,3049$ & $-0,0515$ & d_PX \\
\hline & & 1,0000 & $-0,2334$ & $-0,1078$ & d_BUX \\
\hline & & & 1,0000 & 0,1208 & d_EUR/PLN \\
\hline & & & & 1,0000 & d_EUR/CZK \\
\hline d_EUR/HUF & d_USD/PLN & d_USD/CZK & d_USD/HUF & d_10PLY & \\
\hline$-0,2181$ & $-0,2400$ & $-0,0547$ & $-0,1452$ & $-0,1372$ & d_WIG \\
\hline$-0,1819$ & $-0,0868$ & 0,0688 & $-0,0276$ & $-0,0393$ & d_PX \\
\hline$-0,2921$ & $-0,1106$ & $-0,0228$ & $-0,1457$ & $-0,0623$ & d_BUX \\
\hline 0,5187 & 0,5771 & 0,0943 & 0,3297 & 0,3720 & d_EUR/PLN \\
\hline 0,1029 & 0,0704 & 0,3424 & 0,0640 & 0,0327 & d_EUR/CZK \\
\hline
\end{tabular}


Tabela 5. (cd.)

\begin{tabular}{|l|c|c|c|c|l|}
\hline 1,0000 & 0,3464 & 0,1180 & 0,6155 & 0,3106 & d_EUR/HUF \\
\hline & 1,0000 & 0,8189 & 0,8597 & 0,2203 & d_USD/PLN \\
\hline & & 1,0000 & 0,8079 & 0,0428 & d_USD/CZK \\
\hline & & & 1,0000 & 0,1911 & d_USD/HUF \\
\hline & & & & 1,0000 & d_10PLY \\
\hline & & & d_10CZY & d_10HUY & \\
\hline & & & 0,0404 & $-0,1526$ & d_WIG \\
\hline & & & 0,0682 & $-0,1110$ & d_PX \\
\hline & & & 0,0918 & $-0,0952$ & d_BUX \\
\hline & & & 0,0703 & 0,3277 & d_EUR/PLN \\
\hline & & & $-0,1159$ & 0,0204 & d_EUR/CZK \\
\hline & & & 0,0783 & 0,3473 & d_EUR/HUF \\
\hline & & & 0,0379 & 0,1900 & d_USD/PLN \\
\hline & & & $-0,0433$ & 0,0338 & d_USD/CZK \\
\hline & & & 0,0450 & 0,2043 & d_USD/HUF \\
\hline & & & 0,3876 & 0,6365 & d_10PLY \\
\hline & & & 1,0000 & 0,2709 & d_10CZY \\
\hline & & & & 1,0000 & d_10HUY \\
\hline
\end{tabular}

Źródło: opracowanie własne.

W drugim podokresie nie odnotowano już istotnych współczynników korelacji między rynkami akcji i walut, co może wskazywać na osłabienie transferu kapitału. W przypadku badanych rynków walut w Europie Środkowej występowały istotne współczynniki korelacji liniowej, jednak zaobserwowano również osłabienie relacji. W pierwszym podokresie dominowały wysokie współczynniki korelacji między kursami walut regionu, które po 2012 r. obniżyły się do wartości przeciętnych. Pozwala to jednak przypuszczać, że na waluty regionu oddziałują wspólne czynniki i mimo pewnych różnic poszczególne państwa traktowane są dość podobnie w ramach międzynarodowych transferów kapitału. Największe dysproporcje współczynników korelacji między podokresami zaobserwowano w odniesieniu do rynku obligacji długoterminowych. W pierwszym podokresie w przypadku obligacji polskich i węgierskich odnotowano dość liczne przeciętnie wysokie współczynniki korelacji liniowej z rynkami akcji i walut. Dla rynków akcji korelacja była ujemna, a dla rynków walut - dodatnia. Pozwoliło to na stworzenie pewnego scenariusza transferów kapitału między rynkami, zgodnie z którym napływający kapitał zagraniczny umacniał waluty regionu, powodując spadek kursów w stosunku do EUR i USD. Następnie kapitał zagraniczny był lokowany na rynkach regionu, a inwestorzy kupowali obligacje, powodując wzrost ich cen i spadek rentowności, oraz nabywali akcje, przyczyniając się do zwyżek indeksów giełdowych. Siła tych relacji w drugim podokresie osłabła, ale 
utrzymały się przeciętne dodatnie współczynniki korelacji z kursami EUR oraz wysoka korelacja między obligacjami polskimi a węgierskimi. Relacje tego typu nie zachodziły w przypadku obligacji czeskich, które były jedynie umiarkowanie dodatnio skorelowane z obligacjami polskimi. Może to wynikać ze specyfiki instrumentów czeskich i ich nieco innej charakterystyki inwestycyjnej. Instrumenty czeskie miały najniższą $\mathrm{w}$ regionie premię ( $\mathrm{w}$ odniesieniu do obligacji niemieckich), a w 2006 r. ich rentowność była niższa niż bundy, co może świadczyć o ich odmiennej pozycji w międzynarodowych transferach kapitałów.

Analiza wykorzystująca współczynniki korelacji liniowej wykazała dość liczne zależności krótkoterminowe między segmentami rynku finansowego w państwach Europy Środkowej, ale również tendencję do osłabiania się relacji między poszczególnymi aktywami.

Zależności długoterminowe dla segmentów rynku finansowego Europy Środkowej badano za pomocą analizy kointegracji w procedurze Engle'a-Grangera. Zbadano tygodniowe dane o notowaniach badanych instrumentów w poszczególnych państwach dla całego zakresu czasowego, czyli od stycznia 2006 r. do grudnia 2019 r. Badanie przeprowadzono w czterech etapach, a w ostatnim kro$\mathrm{ku}$ testowano występowanie pierwiastka jednostkowego dla procesu resztowego $\mathrm{z}$ równania kointegrującego. Jeśli otrzymane wartości asymptotyczne $p$ były wyższe niż 0,05 , to nie było podstaw do odrzucenia hipotezy zerowej o występowaniu pierwiastka jednostkowego dla procesu resztowego. Oznaczało to, że proces resztowy jest zintegrowany i kointegracja między zmiennymi nie występuje. Wyniki przeprowadzonych estymacji równań kointegrujących zamieszczono w Tabeli 6 .

Tabela 6. Wyniki badania kointegracji za pomocą procedury Engle'a-Grangera dla obserwacji tygodniowych w okresie styczeń 2006 - grudzień 2019

\begin{tabular}{|l|l|c|l|l|c|}
\hline $\begin{array}{c}\text { Zmienna } \\
\text { zależna }\end{array}$ & $\begin{array}{c}\text { Zmienna } \\
\text { niezależna }\end{array}$ & $\begin{array}{c}\text { Asymptotyczna } \\
\text { wartość } \boldsymbol{p}\end{array}$ & $\begin{array}{c}\text { Zmienna } \\
\text { zależna }\end{array}$ & $\begin{array}{c}\text { Zmienna } \\
\text { niezależna }\end{array}$ & $\begin{array}{c}\text { Asymptotyczna } \\
\text { wartość } \boldsymbol{p}\end{array}$ \\
\hline WIG & PX & 0,6767 & EUR/PLN & USD/PLN & 0,0908 \\
\hline PX & WIG & 0,5015 & USD/PLN & EUR/PLN & 0,3904 \\
\hline WIG & BUX & 0,5670 & EUR/PLN & $10 P L Y$ & 0,1015 \\
\hline BUX & WIG & 0,9849 & 10 PLY & EUR/PLN & 0,8029 \\
\hline BUX & PX & 0,9977 & USD/PLN & 10 PLY & 0,1255 \\
\hline PX & BUX & 0,5044 & 10 PLY & USD/PLN & 0,3561 \\
\hline EUR/PLN & EUR/CZK & 0,3089 & PX & EUR/CZK & 0,4299 \\
\hline EUR/CZK & EUR/PLN & 0,3244 & EUR/CZK & PX & 0,2422 \\
\hline EUR/PLN & EUR/HUF & 0,1397 & PX & USD/CZK & 0,3838 \\
\hline EUR/HUF & EUR/PLN & 0,5866 & USD/CZK & PX & 0,4714 \\
\hline EUR/CZK & EUR/HUF & 0,2826 & PX & $10 C Z Y$ & 0,4181 \\
\hline EUR/HUF & EUR/CZK & 0,8030 & $10 \mathrm{CZY}$ & PX & 0,8773 \\
\hline USD/PLN & USD/CZK & 0,4188 & EUR/CZK & USD/CZK & 0,5233 \\
\hline USD/CZK & USD/PLN & 0,2233 & USD/CZK & EUR/CZK & 0,8156 \\
\hline
\end{tabular}


Tabela 6. (cd.)

\begin{tabular}{|l|l|c|l|l|c|}
\hline $\begin{array}{c}\text { Zmienna } \\
\text { zależna }\end{array}$ & $\begin{array}{c}\text { Zmienna } \\
\text { niezależna }\end{array}$ & $\begin{array}{c}\text { Asymptotyczna } \\
\text { wartość } \boldsymbol{p}\end{array}$ & $\begin{array}{c}\text { Zmienna } \\
\text { zależna }\end{array}$ & $\begin{array}{c}\text { Zmienna } \\
\text { niezależna }\end{array}$ & $\begin{array}{c}\text { Asymptotyczna } \\
\text { wartość } \boldsymbol{p}\end{array}$ \\
\hline USD/PLN & USD/HUF & 0,1270 & $10 \mathrm{CZY}$ & EUR/CZK & 0,9039 \\
\hline USD/HUF & USD/PLN & 0,2530 & EUR/CZK & $10 \mathrm{CZY}$ & 0,2368 \\
\hline USD/CZK & USD/HUF & 0,1822 & $10 \mathrm{CZY}$ & USD/CZK & 0,2061 \\
\hline USD/HUF & USD/CZK & 0,5473 & USD/CZK & $10 \mathrm{CZY}$ & 0,0522 \\
\hline $10 \mathrm{PLY}$ & $10 \mathrm{CZY}$ & 0,8940 & $\mathrm{BUX}$ & $\mathrm{EUR} / \mathrm{HUF}$ & 0,8733 \\
\hline $10 \mathrm{CZY}$ & $10 \mathrm{PLY}$ & 0,8187 & $\mathrm{EUR} / \mathrm{HUF}$ & $\mathrm{BUX}$ & 0,3912 \\
\hline $10 \mathrm{PLY}$ & $10 \mathrm{HUY}$ & 0,1256 & $\mathrm{BUX}$ & $\mathrm{USD} / \mathrm{HUF}$ & 0,8096 \\
\hline $10 \mathrm{HUY}$ & $10 \mathrm{PLY}$ & 0,1201 & $\mathrm{USD} / \mathrm{HUF}$ & $\mathrm{BUX}$ & 0,4821 \\
\hline $10 \mathrm{CZY}$ & $10 \mathrm{HUY}$ & 0,7089 & $\mathrm{BUX}$ & $10 \mathrm{HUY}$ & 0,9077 \\
\hline $10 \mathrm{HUY}$ & $10 \mathrm{CZY}$ & 0,7804 & $10 \mathrm{HUY}$ & $\mathrm{BUX}$ & 0,7315 \\
\hline WIG & EUR/PLN & 0,6047 & $\mathrm{EUR} / \mathrm{HUF}$ & $\mathrm{USD} / \mathrm{HUF}$ & 0,0520 \\
\hline EUR/PLN & WIG & 0,2511 & $\mathrm{USD} / \mathrm{HUF}$ & $\mathrm{EUR} / \mathrm{HUF}$ & 0,0983 \\
\hline WIG & USD/PLN & 0,3823 & $10 \mathrm{HUY}$ & $\mathrm{EUR} / \mathrm{HUF}$ & 0,1678 \\
\hline USD/PLN & WIG & 0,4858 & EUR/HUF & $10 \mathrm{HUY}$ & 0,0638 \\
\hline WIG & $10 \mathrm{PLY}$ & 0,1440 & $10 \mathrm{HUY}$ & USD/HUF & 0,0875 \\
\hline $10 \mathrm{PLY}$ & WIG & 0,4806 & USD/HUF & $10 \mathrm{HUY}$ & 0,0649 \\
\hline
\end{tabular}

Źródło: opracowanie własne.

W przypadku żadnego z analizowanych instrumentów nie potwierdzono kointegracji między badanymi zmiennymi. W kilku przypadkach wartość asymptotyczna $p$ była niska dla zależności między kursami walutowymi oraz kursami walutowymi i rentownościami obligacji, jednak należy podkreślić, że $p$ było wyższe od 0,05 i niższe od 0,1 , co nie pozwoliło jednoznacznie odrzucić hipotezy o integracji procesu resztowego z równania kointegrującego. Oznacza to, że badane zmienne nie charakteryzowały się wspólnymi trendami ani nie występowała między nimi relacja długookresowej równowagi.

\section{Podsumowanie}

Przeprowadzona analiza zależności krótko- i długoterminowych dotycząca rynków finansowych w Czechach, Polsce i na Węgrzech potwierdziła występowanie pewnych relacji między badanymi zmiennymi oraz ich niestabilność w czasie, co jest zgodne z obserwacjami Czapkiewicz i Jamer (2015).

Zależności krótkoterminowe analizowano za pomocą współczynników korelacji liniowej dla pierwszych różnic tygodniowych danych o notowaniach instrumentów rynków akcji, walut i długoterminowych obligacji w Czechach, Polsce i na Węgrzech. Aby ocenić stabilność badanych relacji, okres analizy podzielono na dwa podokresy obejmujące lata 2006-2012 oraz 2013-2019. Wyniki badań 
potwierdziły występowanie zależności krótkookresowych między zmiennymi. Odnotowano przeciętne i wysokie współczynniki korelacji między indeksami akcji oraz kursami walut poszczególnych państw. Należy jednak podkreślić, że w drugim podokresie badawczym nastąpiło osłabienie relacji. W pierwszym podokresie odnotowano istotne korelacje między rynkiem akcji i walut oraz rynkami obligacji, akcji i walut. Może to oznaczać - i jest to dość prawdopodobne - funkcjonowanie międzynarodowego modelu portfelowego transferu kapitału. Inwestorzy zagraniczni kierowali kapitał do państw Europy Środkowej, co skutkowało umacnianiem walut lokalnych, a pozyskane z wymiany walutowej środki były następnie inwestowane w lokalne aktywa finansowe. Inwestorzy nabywali obligacje, wpływając na wzrost ich cen, a co za tym idzie - spadek rentowności, oraz kupowali akcje, przyczyniając się do zwyżki indeksów giełdowych. Kiedy wzrastała awersja do ryzyka na rynkach międzynarodowych, sytuacja się zmieniała - inwestorzy zagraniczni masowo wycofywali aktywa ze wszystkich państw Europy Środkowej, powodując osłabienie walut lokalnych, wzrost rentowności obligacji oraz spadek indeksów giełdowych. W drugim podokresie badawczym nie zaobserwowano już tak istotnych relacji między poszczególnymi segmentami rynku finansowego, co może wskazywać na stopniowe odchodzenie od postrzegania całego regionu jako jednego celu alokacji.

Do zbadania zależności długoterminowych między rynkami akcji, walut i obligacji w Europie Środkowej posłużono się analizą kointegracji, która nie potwierdziła relacji długookresowej równowagi między zmiennymi. Brak kointegracji oznacza, że nie odnotowano wspólnych długookresowych trendów dla zmiennych. Poszczególne instrumenty różniły się specyfiką inwestycyjną, co mogło być przyczyną odmiennego przebiegu notowań w długim okresie. Wydawało się, że najbardziej prawdopodobne było wystąpienie kointegracji na rynkach walutowych - wskazywała na to we wcześniejszych badaniach Witkowska (2011). Okazało się jednak, że w przypadku badanej próby nie potwierdzono kointegracji kursów walutowych, a istotniejsze okazały się różnice między poszczególnymi państwami przekładające się na brak długoterminowej równowagi w notowaniach walut na rynkach Europy Środkowej.

\section{Bibliografia}

Aggarwal R. (1981), Exchange Rates and Stock Prices: A Study of the US Capital Markets under Floating Exchange Rates, „Akron Business and Economic Review", 12.

Agmon T. (1972), The Relations Among Equity Markets in the United States, United Kingdom, Germany and Japan, „Journal of Finance”, 28. 
Andersson M., Krylova E., Vähämaa S. (2008), Why Does the Correlation between Stock and Bond Returns Vary Over Time?, „Applied Financial Economics", 18(2).

Branson W.H. (1983), Macroeconomic Determinants of Real Exchange Risk, [w:] R.J. Herring (red.), Managing Foreign Exchange Risk, Cambridge University Press, Cambridge.

Buszkowska E. (2014), Badanie zależności między indeksami giełdowymi a kursami walutowymi, ,Zeszyty Naukowe Uniwersytetu Ekonomicznego w Krakowie", 4(928).

Czapkiewicz A., Jamer P. (2015), Dynamika współzależności Warszawskiej Gietdy Papierów Wartościowych z innymi rynkami finansowymi, „Ekonometria”, 2(48).

Demian C.V. (2011), Cointegration in Central and East European markets in light of EU accession, „Journal of International Financial Markets, Institutions \& Money", 21(1).

Dickey D.A, Fuller W.A. (1979), Distribution of the Estimators for Autoregressive Time-Series with a Unit Root, ,Journal of the American Statistical Association", 74(366).

Doman M., Doman R. (2011), The Impact of the Exchange Rate Dynamics on the Dependencies in Global Stock Market, „Dynamic Econometric Models”, 11.

Dornbusch R., Fischer S. (1980), Exchange Rates and the Current Account, „American Economic Review”, 70(5).

Dyduch J. (2016), Analiza zależności dtugookresowych między indeksem WIG $i$ indeksem obligacji skarbowych TBSP.INDEX, „Studia Ekonomiczne. Zeszyty Naukowe Uniwersytetu Ekonomicznego w Katowicach", 282.

Embrechts P., Neil A.M., Straumann D. (1999), Correlation: Pitfalls and Alternatives, „Risk”, May.

Fiszeder P. (2000), Econometric Analysis of the World Stock Indices and Exchange Rates and their Influence on the Warsaw Stock Exchange, „Dynamic Econometric Models", 4.

Frankel J.A. (1983), Monetary and Portfolio-Balance Models of Exchange Rate Determination [w:] Bhandari J.S., Putnam B.H. (red.), Economic Interdependence and Flexible Exchange Rates, MIT Press, Cambridge.

Gjika D., Horvath R. (2013), Stock Market Comovements in Central Europe: Evidence from the Asymmetric DCC Model, „Economic Modelling”, 33.

Hilliard J.E. (1979), The Relationship Between Equity Indices on World Exchanges, ,Journal of Finance”, 34(1).

Hołubowicz K. (2014), Korelacja indeksów cen akcji na globalnych rynkach finansowych, „Nauki o Finansach”, 2(19).

Ilmanen A. (2003), Stock-Bond Correlations, „Journal of Fixed Income”, 13(2). 
Kliber A., Kliber P. (2010), Zależności pomiędzy kursami walut środkowoeuropejskich w okresie kryzysu 2008, „Przegląd Statystyczny”, 57(1).

Kwiatkowski D., Phillips P.C.B., Schmidt P., Shin Y. (1992), Testing the Null Hypothesis of Stationarity Against the Alternative of a Unit Root: How Sure Are We that Economic Time Series Have a Unit Root?, „Journal of Econometrics", 54(1-3).

Lothian J.R. (2002), Internationalization of Money and the Globalization of Financial Markets, ,Journal of International Money and Finance”, 21(6).

Ma C.K., Kao G.W. (1990), On Exchange Rate Changes and Stock Price Reactions, „Journal of Business Finance and Accounting”, 17(3).

Maddala G.S. (2006), Ekonometria. Warszawa: Wydawnictwo Naukowe PWN.

Malliaris A.G., Urrita J. (1992), The International Crash of October 1987: Causality Tests, „Journal of Financial and Quantitative Analysis”, 27(3).

Soenen, L., Hennigar E. (1988), An Analysis of Exchange Rates and Stock Prices: The US Experience between 1980 and 1986, „Akron Business and Economic Review", 19.

Syllignakis M.N., Kouretas G.P. (2011), Dynamic Correlation Analysis of Financial Contagion: Evidence from the Central and Eastern European Markets, „International Review of Economics and Finance”, 20(4).

Syriopoulos T. (2004), International Portfolio Diversification to Central European Stock Markets, „Applied Financial Economics”, 14(17).

Witkowska D. (2011), Kointegracja kursów walutowych Polski, Węgier i Czech, „Metody Ilościowe w Badaniach Ekonomicznych”, 12(2).

Zielonka P., Foltyński P. (1999), Korelacje pomiędzy stopami zwrotu wybranych giełd papierów wartościowych $w$ drugiej połowie lat 90, „Nasz Rynek Kapitałowy", 101.

\section{Streszczenie}

Celem artykułu jest przeanalizowanie korelacji i kointegracji rynku akcji, rynku obligacji skarbowych oraz rynku walutowego w Czechach, Polsce i na Węgrzech. Analiza obejmuje 14 lat, począwszy od stycznia 2006 r., a skończywszy na grudniu 2019 r. Badanie wykazało korelacje między zmiennymi, które były niestabilne w podokresach. Zastosowany w analizie test Engle'a-Grangera nie potwierdził kointegracji między analizowanymi zmiennymi.

Stowa kluczowe: rynki finansowe, korelacja, kointegracja 


\section{Summary}

Analysis of interdependence on the financial markets of Central Europe

The aim of this article is to analyze the correlation and cointegration between the stock market, the treasury bond market, and the currency market in the Czech Republic, Poland, and Hungary. The analysis covers a fourteen-year period (January 2006 - December 2019). The study found correlations between variables, but they were unstable between subperiods. The Engle-Granger test applied in the cointegration analysis did not confirm the cointegration between the analyzed variables.

Keywords: financial markets, correlation, cointegration

JEL: C32, G01, G15 